\title{
Akıllı Kentlerde Çevresel, Sosyal ve Ekonomik Sürdürülebilirlik, Kopenhag Örneği
}

\author{
Seval CÖMERTLER ${ }^{1 *(D)}$, Necmiye CÖMERTLER ${ }^{2}$ (D) \\ ORCID 1: 0000-0001-9823-1509 \\ ORCID 2: 0000-0002-0370-843X \\ ${ }^{1}$ Dr. Şehir Plancısı \\ ${ }^{2}$ Aydın Adnan Menderes Üniversitesi, Nazilli iktisadi ve Idari Bilimler Fakültesi, iktisat Bölümü, 09800, Aydın, Türkiye. \\ *e-mail: sevalcomertler@gmail.com \\ Öz \\ Akıllı kent teknolojilerinin amaç değil, kentsel sürdürülebilirliği sağlamada faydalı bir araç olarak \\ değerlendirildiği şehirler, diğer kentler için yol gösterici niteliktedir. Bu çalışmada akıllı kentlerdeki çevresel, \\ sosyal ve ekonomik sürdürülebilirliğin akıllı kent endekslerinde üst sıralarda yer alan Kopenhag örneğinde \\ incelenmesi amaçlanmıştır. Araştırmanın bulgularına göre, Kopenhag'da uygulanan entegre ulaşım sistemi, \\ rüzgar enerjisi, atık yönetimi gibi akıllı kent çözümleri bir yandan hava kirliliğinin, sel riskinin, gürültünün ve \\ yenilenemeyen kaynaklar üzerindeki baskının azalması; diğer yandan daha hızlı, daha güvenli, daha sağlıklı, \\ daha ucuz ve daha az stresli ulaşım imkanlarının gelişmesi, yeşil ekonominin güçlenmesi, iş dünyası ve pazarın \\ canlanması gibi pek çok sosyal, ekonomik ve çevresel fayda sağlamıştır. Ortaya koyduğu yenilikçi, bütüncül ve \\ uzun vadeli uygulamalar ile Kopenhag sosyo-ekonomik ve çevresel sürdürülebilirlik arasında denge kurmaya \\ çalışan diğer kentler için iyi bir örnek teşkil etmektedir.
}

Anahtar Kelimeler: Akıllı kentler, sürdürülebilirlik, Kopenhag

\section{Environmental, Social and Economic Sustainability in Smart Cities, the Case of Copenhagen}

\begin{abstract}
Cities, where smart city technologies are not a goal, but are evaluated as a useful tool to ensure urban sustainability, are guides for other cities. This study aims to examine the environmental, social and economic sustainability in smart cities in the case of Copenhagen, which is at the top of the smart city indexes. According to the findings, in Copenhagen, smart solutions such as integrated transportation system, wind energy and waste management has provided many socio-economic and environmental benefits such as decrease in air pollution, decrease in flood risk, decrease in noise, less pressure on non-renewable sources, development of faster, safer, healthier, cheaper and less stressful transportation opportunities, strengthening green economy, revival of the business world and the market. Copenhagen with its innovative, holistic and long-term practices, is a good example for other cities, which seeks to balance socio-economic and environmental sustainability.
\end{abstract}

Keywords: Smart cities, sustainability, Copenhagen

Atıf/Citation: Cömertler, S, Cömertler, N. (2021). Akıllı Kentlerde Çevresel, Sosyal ve Ekonomik Sürdürülebilirlik, Kopenhag Örneği. Journal of Architectural Sciences and Applications, 6 (1), 317-333. DOI: 10.30785/mbud.780116 


\section{Giriş}

1950 yılında 2,5 milyar olan dünya nüfusu 2019'da 7,7 milyara ulaşmış olup, 2050 yılına gelindiğinde bu değerin 9,7 milyara yükselmesi beklenmektedir (United Nations, 2019a: 5). Artan dünya nüfusu, aynı zamanda kentleşmesine de devam etmektedir. Birleşmiş Milletler'in "Dünya Kentleşme Beklentileri" raporuna göre, 1950'de kentlerde yaşayan kişi sayısı 751 milyon iken, 2018'de 4 milyarı aşmıştır. 2050 yılı için yapılan hesaplamalara göre, o dönemde 6,7 milyar kişinin kentsel alanlarda yaşaması beklenmektedir (United Nations, 2019b: 25). Diğer bir ifadeyle kentsel nüfus 1950'de dünya nüfusunun yalnızca \%29,6'sını oluştururken, 2018 yılında bu oran \%55'e yükselmiştir. Birleşmiş Milletler'in hazırladığı söz konusu rapora göre, dünya genelinde kentsel nüfus oranının 2050 yılında \%68,4'e yükselmesi beklenmektedir. Dolayısıyla önümüzdeki yıllarda kentleşmenin devam etmesi ve 2050 yılına gelindiğinde Afrika ve Asya'nın bir bölümü hariç diğer kıtalarda kentsel nüfus oranının \%75'i aşması öngörülmektedir (United Nations, 2019b: 21-26).

Gelişmiş ülkelerde Endüstri Devrimi sonrasında, dünyanın birçok bölgesinde ise önemli ölçüde 20 . yüzyılda yaşanan ve hali hazırda devam etmekte olan bu kentleşme süreci hava kirliliği, su kirliliği, gürültü, atık sorunu, trafik, gecekondu, kentsel saçaklanma, küresel ısınma vb. birçok çevre sorununu beraberinde getirmiştir. Kentleşmeyle birlikte gelişen sorunların çözümü için Yeni Şehircilik Hareketi, Akıllı Büyüme Yaklaşımı, Sürdürülebilir Kentler, Yeşil Kentler, Ekolojik Kentler gibi pek çok model ve yaklaşım ortaya konulmuş, yeni hareketler gelişmiştir. Ancak, kentsel yaşam kalitesini yükseltmeyi hedefleyen bu yaklaşımların hiç biri bütünüyle başarılı olamamış ve yeni teknolojilerin kullanılmasına odaklanan Dijital Kent, Zeki Kent, Sanal Kent, Yetenekli Kent, Siber Kent ve Bilgi Kenti gibi yeni modeller ortaya çıkmıştır. Bu süreçte kentsel yaşam kalitesini yükseltmek ve kentsel sürdürülebilirliği sağlamak için geliştirilen modellerin kapsayıcısı ve son noktası olarak Akıllı Kent yaklaşımı yeni bir paradigma olarak ortaya çıkmıştır (Kentsel sürdürülebilirliğin sağlanması ve yaşam kalitesinin yükseltilmesi için geliştirilen akıllı kent kavramı ve diğer yeni planlama yaklaşımları ve modelleri hakkında ayrıntılı bilgi ve karşılaştırmalı değerlendirmeler için bkz. Karakurt Tosun, 2019; Anthopoulos, 2017; Eremia, Toma ve Sanduleac, 2017; European Parliament, 2014; Kunzmann, 2014; Dameri, 2013; Sınmaz, 2013). Zira akıllı kent kavramı sadece teknoloji odaklı olan Dijital Kent, Bağlantılı Kent, Zeki Kent ve Bilgi Kenti gibi kavramlardan farklı olarak, teknolojinin yanı sıra insanı ve kurumları da merkezine almaktadır. Dolayısıyla, ekonomi, çevre, insan vd. tüm bileşenleriyle akıllı kent münferit teknolojik çözümlerden ziyade birçok sektörü etkileyen bir dönüşümdür (DeloitteVodafone, 2016).

Yirminci yüzyıl boyunca, hızlı kentleşmeyle birlikte gelişen çevre sorunları Birleşmiş Milletler'in de gündemine girmiş ve günümüze kadar önemini hep korumuştur. Bu bağlamda, çevre sorunlarına çözüm arayışları ve sürdürülebilirlik meselesi Birleşmiş Milletler'in çatısı altında 1976 yılından bu yana her yirmi senede bir düzenlenen Habitat Konferanslarında ve Birleşmiş Milletler Çevre ve Kalkınma Konferansı, Birleşmiş Milletler Nüfus ve Kalkınma Konferansı, Rio +5 Toplantısı, Birleşmiş Milletler Bin Yıl Zirvesi, Johannesburg Zirvesi ve Birleşmiş Milletler Sürdürülebilir Kalkınma Konferansı Rio $+20^{\prime}$ de ve bu toplantıların çıktısı olan raporlarda yer almıştır (Yaylı ve Gönültaş, 2018). 2016 yılında "Konut ve Sürdürülebilir Kentsel Gelişme Konferansı" adıyla gerçekleştirilen Üçüncü Habitat Konferansının sonuç belgesi olan "Yeni Kentsel Gündem" raporunun "Çevresel Olarak Sürdürülebilir ve Dirençli Kentsel Gelişme" başlığı altında yer alan 66. maddesinde "dijitalleşme, temiz enerji ve teknolojilerin yanı sıra yenilikçi ulaşım teknolojilerinden yararlanan akılı bir kent yaklaşımının benimsenmesi, böylece kent sakinlerine daha fazla çevre dostu seçenekler sunulması, sürdürülebilir ekonomik büyümenin artırılması ve hizmet sunumunun iyileştirilmesi" taahhüt edilmiştir (United Nations, 2017: 18). Yeni Kentsel Gündem raporunda işaret edildiği üzere, günümüzde, şehirleri daha yaşanabilir ve çevre dostu yerler haline getirmek, yanı sıra geleceğin ekonomisinde gelişebilmek amacıyla da akıllı kentlere intiyaç duyulmaktadır. Zira gelişen teknolojinin doğru değerlendirilmesiyle bir yandan doğal kaynaklar muhafaza edilirken, bir yandan da sunulan yeni ürünler, hizmetler ve iş modelleriyle akıllı kent çözümleri şehirlerin ekonomik gelişimine katkıda bulunmaktadır. Örneğin, Tokyo, 54 milyon dolar harcayarak değiştirdiği su tedarik borularıyla ve elektronik sızıntı detektörleriyle su kaybını \%3,7 oranında azaltarak 172,4 milyon dolar tasarruf sağlamıştır. Böylece, Tokyo'daki akıllı su sistemiyle ilk maliyetin 3 katı tasarruf sağlanmıştır (Deloitte-Vodafone, 2016: 57). ABD'de ise Georgia, Tennessee 
ve Kuzey Karolina eyaletlerinde yüklenen 15.000 akıllı sayaç, operasyon maliyetlerinin \%65, ödenmeyen fatura borçlarının \%50 azalmasını sağlamıştır (Deloitte-Vodafone, 2016: 55). Seul'un turistik Bukchon semtinde ise çöp kutularına sensör yerleştirilerek çöp toplama faaliyetleri daha düzenli gerçekleştirilmiş, bu sayede çöp toplama maliyeti \%43 oranında azaltılmış, ayrıca bölgede artan turizme katkı sağlanmıştır (Deloitte-Vodafone, 2016: 60).

Bugün dünyada ve Türkiye'de birçok yerel yönetim, kentsel hizmetleri kolaylaştırması yanı sıra çevresel ve ekonomik çıktıları nedeniyle akıllı kent kavramına ve akıllı kent çözümlerine giderek daha fazla ilgi göstermektedir. Bu ilgi beraberinde büyük bir endüstriyi de meydana getirmektedir. Anthopoulos'a (2017) göre hâlihazırda IBM, CISCO, Alcatel-Lucent, Hitachi, Siemens ve Huawei gibi birçok teknoloji devi şirketin domine ettiği ve istikrarlı bir şekilde büyüyen akıllı kent endüstrisi 2025 yılına kadar 1 trilyon Amerikan Dolarını aşacaktır. Ancak sahip olduğu "akıllı" ön adı sebebiyle teknolojik gelişmeyi simgeleyen yaklaşım çoğu zaman aşırı teknoloji odaklı olarak algılanmakta ve sadece bu doğrultuda çalışmalar yapılmaktadır. Bu durum, bir yandan birçok kentte ölü yatırımların gerçekleştirilmesine neden olurken, bir yandan da akıllı kent yaklaşımının sürdürülebilirlik bağlamından uzaklaşmasına ve bütüncül nitelikteki anlamını yitirmesine yol açmakta ve hatta teknoloji tekellerinin elinde endüstriyel hileler için bir araca dönüşsmesine sebep olabilmektedir (ayrıca bkz. Gürsoy, 2019; Hollands, 2008).

Akıllı kent teknolojilerinin amaç değil, kentsel sürdürülebilirliği sağlamada faydalı bir araç olarak değerlendirildiği başarılı akıllı kentlerin incelenmesi; Avrupa, Amerika ve Uzak Doğu Asya ülkelerine kıyasla, akıllı kent çalışmalarında görece başlangıç aşamasında olan kentler için yol gösterici olacaktır. Bu görüşten hareketle, araştırmada akıllı kentlerdeki çevresel, sosyal ve ekonomik sürdürülebilirliğin, yüksek çevre kalitesi Avrupa Komisyonu tarafından onaylanan ve ödüllendirilen, yeşil ekonomi lideri Yeşil Başkent Kopenhag kenti örneğinde incelenmesi amaçlanmıştır.

\section{Materyal ve Yöntem}

Çalışmada doküman analizi yöntemi kullanılmıştır. Bu çerçevede akıllı kentler (smart cities), sürdürülebilirlik (sustainability) ve Kopenhag (Copenhagen) anahtar kelimeleri kullanılarak ulusal ve uluslararası alan yazın taranmış, konu ile ilgili güncel makale, bildiri, rapor ve tezler saptanmış ve incelenmiştir.

Çalışma dört ana başlıkta organize edilmiştir. Araştırma problemi ve amacının ortaya konulduğu giriş bölümünü müteakip, çalışmanın yöntem ve organizasyonu açıklanmıştır. Ardından, sürdürülebilirlik, sürdürülebilir kalkınma ve sürdürülebilir kentsel gelişme kavramları açıklanmıştır. Akıllı Kentler başlığı altında ise, öncelikle akıllı kent kavramı tanımlanmış, ardından akıllı kent bileşenleri, teknolojileri ve uygulamaları açıklanmış, dünyadaki akıllı kent örnekleri ortaya konulmuştur. Kavramsal ve kuramsal arka planın ortaya konulmasını müteakip, Kopenhag'daki akıllı kent uygulamaları Kopenhag Çözümleri Laboratuvarı web sitesinden yararlanılarak açıklanmışır. Kentsel meselelere ilişkin geliştirilen diğer sürdürülebilir çözümler ve elde edilen sosyo-ekonomik-çevresel kazanımlar Kopenhag şehir yönetiminin hazırladığı raporlardan yararlanılarak ortaya konulmuştur. Sonuç kısmında bulguların genel bir değerlendirmesi yapılmış, sonraki çalışmalar için öneri geliştirilmiştir.

\section{Bulgular ve Tartışma}

\subsection{Sürdürülebilirlik, Sürdürülebilir Kalkınma ve Sürdürülebilir Kentsel Gelişme}

Latincede, sustinere (dayanmak, ayakta kalmak, desteklemek, korumak, sürdürmek) ve susceptibilis (yetenekli, sürdürülebilir, duyarlı) kelimelerinden türetilen sürdürülebilirlik kavramının ortaya çıkışı eski olsa da, yaygın kullanımı 1972'den sonra gerçekleşmiştir (Özgen, 2019: 2). Sürdürülebilirlik kavramı, etimolojik olarak, sürdürmek, sağlamak, devam ettirmek, desteklemek, var olmak anlamlarında kullanılmaktadır. Daha geniş bir çerçevede, sürdürebilirlik, doğaya ve çevreye zarar vermeden, doğanın sunduğu sınırlı kaynaklardan yararlanmayı olabildiğince uzun bir süreye yaymak, benzer şekilde toplumsal ilişkilerde de adil ve çoğunlukçu bir yetki ve paylaşıma açık, şeffaf yönetsel ilişkiler manzumesini etkin kılmaktır (Özgen, 2019: 2). 
Sürdürülebilirlik kavramı ile iç içe geçen sürdürülebilir kalkınma olgusu, kentleşme, teknolojik ilerlemeler ve ekonomik gelişmelerin bir sonucu olarak ortaya çıkan çevre sorunlarının önlenmesi, doğal kaynakların ve çevrenin korunarak gelecek nesillere aktarılmasının sağlanması istenci ile gelişmiştir. 1972 yılında Birleşmiş Milletler tarafından düzenlenen İnsan ve Çevresi Konferansı'nda temelleri atılan sürdürülebilir kalkınma olgusu, 1987 'de Birleşmiş Milletler'in Dünya Çevre ve Gelişme Komisyonu tarafından yayınlanan ve Brundtland Raporu olarak da bilinen "Ortak Geleceğimiz" raporunda bir politika kavramı olarak ele alınmıştır. Kalkınma ile çevre konularını birleştiren bu raporda, sürdürülebilir kalkınma kavramı "bugünün ihtiyaçlarını gelecek nesillerin kendi ihtiyaçlarını karşılayabilme yeteneklerinden taviz vermeden karşılayan gelişme" olarak tanımlanmıştır (United Nations, 1987). Johnston vd. (2007), Brundtland Raporundan sonraki iki yıl içinde, yaklaşık 140 farklı sürdürülebilir kalkınma tanımının ortaya çıktığını, yirmi yıl içinde ise, pek çok disiplinin konuya kendi perspektiflerinden yaklaşmaları sonucunda kavrama ilişkin yapılan tanımlamaların sayısının 300'ü geçtiğini belirtmektedir.

Zamanla kavram, genel olarak sürdürülebilirliğin sosyal, ekonomik ve çevresel olmak üzere üç boyutunu kapsayacak şekilde yorumlanmış ve bu boyutların dengeli bir şekilde ele alınması gerekliliği üzerinde durulmuştur. Sürdürülebilir kalkınmanın çevre boyutu hava/atmosfer, kara, deniz/okyanus, toprak, su ve biyolojik çeşitlilik gibi temel konuları içermektedir. Öte yandan, ekonomik boyuta ilişkin başlıca konular ekonomik faaliyetler, üretim ve tüketim alışkanlıkları ve ilgili politikalar olarak sıralanmaktadır. Sosyal boyut ise eğitim, barınma, adalet, güvenlik, sağlık, nüfus, siyasal katılım, yönetişim ve sosyo-kültürel politikaları kapsamaktadır (Özgen, 2019: 5). Harris'e (2000) göre, çevresel olarak sürdürülebilir bir sistem istikrarlı bir kaynak tabanı sağlamalı, bu bağlamda bir yandan yenilenebilir kaynakların sömürülmesinden kaçınmalı diğer yandan yenilemeyen kaynaklardan yalnızca yatırımlarla ikame edilmiş olanlarını tüketmeli, ayrıca biyolojik çeşitliliği, atmosferik dengeyi ve ekonomik kaynak olarak sınıflandırılmayan diğer ekosistem işlevlerini korumalıdır. Ekonomik açıdan sürdürülebilir bir sistem ise, bir yandan kesintisiz bir şekilde mal ve hizmet üretebilmeli, diğer yandan devlet borçlarını ve dış borçları yönetilebilir düzeyde koruyabilmeli ve tarımsal veya endüstriyel üretime zarar veren aşırı sektörel dengesizliklerden kaçınabilmelidir. Sosyal açıdan sürdürülebilir bir sistem, sağlık ve eğitim dâhil olmak üzere sosyal hizmetlerin yeterli bir düzeyde karşılanmasını, bunların eşit bir şekilde dağılımını, ayrıca siyasi hesap verebilirlik, katılım ve toplumsal cinsiyet eşitliğini sağlamalıdır (Harris, 2000: 5-6). Özetle, sürdürülebilir kalkınma, bütünsel ve uzun vadeli düşünmeyi gerektiren sistem tabanlı bir yaklaşımdır.

Sürdürülebilir kalkınma kavramının bir uzantısı olarak gelişen sürdürülebilir kentsel gelişmede temel amaç, şehirleri çevresel, ekonomik ve sosyal açıdan sürdürülebilir kılmaktır. Sürdürülebilir kalkınmanın orijinal tanımı doğrultusunda, sürdürülebilir kentsel gelişme "gelir, istihdam, barınma, temel hizmetler, sosyal altyapı ve ulaşımda eşitlik gözetilerek, kentsel alanların gelişimi ile çevrenin korunması arasında denge sağlamak" olarak tanımlanmaktadır (Ahvenniemi vd., 2017: 235). Erbay ve Özden'e (2018) göre, kentler çevresel, ekonomik, politik ve kültürel boyutta ortaya koyacağı uygulamalar ile sürdürülebilirlik hedeflerinin gerçekleştirilmesine pozitif katkı sağlayabilir. Bu bağlamda, Sınmaz (2013) sürdürülebilir kentsel gelişmenin arazi kullanım kararları ve ulaşım ilişkileri ile doğrudan bağlantıları olduğunu ifade etmektedir (Sürdürülebilir kentsel gelişme ile ilgili ayrıntılı bilgi için bkz. Karakurt Tosun, 2019).

\subsection{Akıllı Kentler}

Dünyadaki kentsel nüfus artışıyla birlikte gelişen çevre sorunları karşısında kentsel sürdürülebilirliğin sağlanması ve yaşam kalitesinin yükseltilmesi için çözüm olarak görülen akıllı kent kavramı ilk defa 90'Iı yıllarda ortaya çıkmış, ilerleyen süreçte sürekli olarak gelişmiş, değişmiş ve dönüşmüştür (Anthopoulos, 2017: 7). Geçirdiği dönüşüme koşut akıllı kentin ne olduğuna ilişkin tanımlar, akıllı kent bileşenleri, araçları ve uygulama alanları da çeşitlenmiştir.

\subsubsection{Akıllı kent tanımları ve bileşenleri}

Kentsel yaşamın eğitim, sağlık, çevre, ekonomi gibi birçok boyutu ile ilgili olan ve teknoloji alanında yaşanan gelişmelerden dolayı sürekli değişmekte ve dönüşmekte olan akıllı kent kavramına ilişkin üzerinde uzlaşılmıs tek ve basit bir tanım bulunmamakta, onun yerine, kavrama farklı açılardan 
yaklaşan pek çok tanımla karşılaşılmaktadır (bkz. Albino vd., 2015; Dameri, 2013; Lazaroiu ve Roscia, 2012). Öyle ki, tanımlamaların çokluğu ve çeşitliliği birçok araştırmacıyı bu tanımları kategorize etmeye sevk etmiştir. Örneğin Cocchia (2014) akıllı kent tanımlarını teknoloji temelli, insan temelli ve kurumsal temelli olmak üzere üç kategoride sınıflandırmıştır. Yin vd. (2015) ise akıllı kent tanımlarını dört gruba ayırmışlardır. Bunlar teknolojiye odaklanan tanımlar, uygulama alanına odaklanan tanımlar, sistem entegrasyonuna odaklanan tanımlar ve veri işlemeye odaklanan tanımlardır.

Son yıllarda akıllı kent kavramının akıllı sürdürülebilir kent kavramına evrilmesi ile birlikte, akıllı kent tanımları da sürdürülebilirliğin bütün boyutlarına vurgu yapacak şekilde gelişmiştir. Örneğin Kondepudi vd. 116 akıllı kent tanımını inceledikten sonra akıllı sürdürülebilir kent kavramını şu şekilde tanımlamışlardır:

"Akıllı, sürdürülebilir bir kent, yaşam kalitesini, kentsel işletme ve hizmetlerin verimliliğini ve rekabet gücünü artırmak için bilgi ve iletişim teknolojilerini ve diğer araçları kullanan, aynı zamanda mevcut ve gelecek nesillerin ekonomik, sosyal ve çevresel açıdan ihtiyaçlarını karşılayan yenilikçi bir şehirdir"(Kondepudi vd., 2014: 1).

Akıllı kent kavramının üzerinde uzlaşılmış tek bir tanımı olmadığı için, akılı kent bileşenlerine ilişkin de bir uzlaşı bulunmamaktadır (Silva vd., 2018; Anthopoulos, 2017; Eremia, Toma ve Sanduleac, 2017; Albino vd., 2015). Bununla birlikte, birçok çalışmada, Avrupa Parlamentosu'nun esas aldığı akıllı yönetişim, akıllı ekonomi, akıllı hareketlilik, akıllı çevre, akıllı insanlar ve akıllı yaşam unsurları akıllı kentlerin temel bileşenleri olarak tanımlanmaktadır (European Parliament, 2014).

\subsubsection{Akıllı kent teknolojileri ve uygulama alanları}

Akıllı kentlerin yukarıda geçen bu altı bileşenine yönelik olarak çeşitli bilgi ve iletişim teknolojileri kullanılmaktadır. Bunlar arasında internet, mobil cihazlar, dijital platformlar, büyük veri, açık veri, nesnelerin interneti, bulut teknolojisi, 3 boyutlu baskı, sürücüsüz taşıtlar, sosyal etkileşimli robotlar, insansız hava araçları, GSM, SCADA ve coğrafi bilgi sistemleri başlıca akıllı kent teknolojilerini oluşturmaktadır (Gürsoy, 2019).

Dünyadaki ve Türkiye'deki akıllı kent örnekleri incelendiğinde akıllı şebeke, akıllı sayaç, akıllı ulaşım, akıllı aydınlatma, akıllı atık toplama ve akıllı bina gibi çok geniş bir yelpazede pek çok akıllı kent uygulamasının gerçekleştirildiği görülmektedir. Yin vd. (2015) bu çok çeşitli akıllı kent uygulamalarının her biri alt alanlar içeren dört ana kategoride sınıflandırılabileceğini, bu bağlamda, uygulamaların bir kısmının devletle ilgili alanlarda, bir kısmının çevreyle ilgili alanlarda, diğerlerinin ise iş ve vatandaşlarla ilgili alanlarda gerçekleştirildiğini belirtmektedir. Yin vd. (2015)'e göre, devletle ilgili alanlardaki akıllı kent uygulamaları devletin işleyişini daha verimli hale getirmek için geliştirilen edevlet (Bernardo, 2017), şeffaf hükümet (Johannessen ve Berntzen, 2018), kamu hizmetleri (Emaldi vd., 2017) ve şehir izleme uygulamalarını (Lau vd., 2018) içermektedir. Vatandaşların yaşam kalitesini ve mutluluğunu artırmak için ise akıllı kart ve akıllı toplu taşıma (Pelletier vd., 2011), akıllı trafik (Djahel vd., 2015), akıllı turizm (Gretzel vd., 2015), akıllı eğlence (Nijholt, 2017), akıllı sağılk hizmetleri (Solanas vd., 2014) ve akıllı eğitim (Uskov vd., 2015) uygulamaları gerçekleştirilmektedir. İş alanındaki uygulamalar kurumsal yönetim (Mulligan ve Olsson, 2013), lojistik (Nowicka, 2014), akıllı reklamcılık (Finn ve Wadhwa, 2014), girişimcilik (Hollands, 2008) ve akıllı tarım (Goyal vd., 2019) gibi çözümleri içermektedir. Sürdürülebilir çevre uygulamaları kapsamında ise akıllı şebeke (Farhangi, 2010), akıllı malzeme (Topal ve Arpacıoğlu, 2020), yenilenebilir enerji (Calvillo vd., 2016), akıllı su yönetimi (Parra vd., 2015), akıllı atık yönetimi (Anagnostopoulos vd., 2017), kirlilik kontrolü (Peng vd., 2017), akıllı bina (Kylili ve Fokaides, 2015) ve akıllı evler (Serrenho ve Bertoldi, 2019) öne çıkmaktadır (Akıllı kent uygulamaları ile ilgili ayrıca bkz. Sanchez-Corcuera vd., 2019).

\subsubsection{Dünyada akıllı kent örnekleri}

Eremia vd. (2017)'ne göre dünya gezegeni kentleştikçe, şehirler akıllı olmak zorundadır. Zira kentlerin, aşırı nüfus yığılmaları sonucunda ortaya çıkan yoğun enerji talebinin karşılanması, doğal kaynakların ve çevrenin korunması gibi karmaşık sorunların üstesinden gelebilmek için yenilikçi yollar bulması gerekmektedir. Bu bağlamda birçok ülkede merkezi ve yerel yönetimler akıllı kent çalışmalarını desteklemekte, böylece akıllı kentlerin sayısı hızla artmaktadır. Ancak, dünyadaki akıllı 
kentlerin sayısına ilişkin net ve üzerinde uzlaşılmış bir bilgi yoktur. Zira akıllı kenti tanımlama biçimine göre farklı kaynaklar farklı istatistikler ortaya koymaktadır. Örneğin, Anthopoulos (2017) dünyada 300'den fazla akıllı kentin hali hazırda var olduğunu bildirirken, Gürsoy'un Deloitte'in raporundan aktardığına göre, dünya üzerinde 1000 'den fazla akıllı kent pilot projesi bulunmakta olup, bunların 500 kadarı Çin'de, 90'ı Avrupa'da ve 40'ı ABD'de gerçekleştirilmektedir (Gürsoy, 2019). Özetle, akıllı kentlerin sayısına ilişkin kesin bir bilgi olmasa da, dünyada akıllı kentlere dönüşümün yükselen bir eğilim olduğu açıktır.

Ancak, akıllı kent teknolojilerinin kullanıldığı bütün kentler başarılı ve gerçek bir akıllı kent olarak tanımlanmamaktadır. Bu bağlamda, şehirlerin sadece tellerden ve kablolardan, akıllı ofislerden, popüler barlardan ve lüks otellerden ibaret olmadığına ve kaldı ki insanların bunlardan daha fazlasını hak ettiğine dikkat çeken Hollands (2008), bir kentin salt sofistike bir bilgi teknolojisi altyapısı geliştirerek akıllı olarak etiketlenemeyeceğini ifade etmektedir. Peki, hangi şehirler akıllı kentlere dönüşümün başarılı örnekleridir? Bu sorunun cevabına akıllı kent endeksleri yardımıyla ulaşılabilmektedir (Ayrıntılı bilgi için bkz. Giffinger ve Gudrun, 2010). Örneğin, 2019 Yılı Akıllı Kentler Endeksine göre dünyadaki en başarılı akıllı kent Singapur'dur. İlk onda yer alan diğer en akıllı kentler ise sırasıyla Zürih, Oslo, Cenova, Kopenhag, Auckland, Taipei, Helsinki, Bilbao ve Düseldorf şehirleridir (IMD, 2019). Ayrıca Stokholm, Boston, Tokyo, San Francisco, Amsterdam, Melburn, Barselona, Ottowa, Seul, Viyana, Nice, Santander, Londra, New York, Denver, Paris, Washington ve Berlin dünyadaki akıllı kentler arasında iyi bilinen, bugüne kadar Smart City Index, Juniper Research, Roland Berger gibi uluslararası ölçekte kabul gören endekslere giren ve önceki araştırmalarda ele alınan başarılı örneklerdendir (Güncel bazı araştırmalar için bkz. Sanchez-Corcuera vd., 2019; Silva vd., 2018; Mora ve Bolici, 2017; European Parliament, 2014).

Akıllı kentlerin başarılı olarak tanımlanan bu örneklerinin aksine dünyada birçok başarısız akıllı kent uygulamaları da mevcuttur. Bu kentler bütüncül bir stratejiden uzak, genellikle teknoloji kullanımına aşırı odaklanmış kentlerdir. Ne var ki, akıllı kentlere dönüşümde teknoloji çok önemli bir araç olmakla birlikte, tek başına bir kenti akıllı yapmaya yetmemektedir. Hollands'a (2008) göre, bilgi teknolojilerinin kentleri otomatik olarak dönüştürebileceği ve geliştirebileceğine körü körüne inanmak yerine, akıllı kente dönüşüm sürecinde, işe insanlarla ve denklemin beşeri sermaye yönüyle başlanması gereklidir. Zira teknoloji otomatik olarak akıllı topluluklar meydana getiremez, ancak, insanların güçlendirilmesi ve eğitilmesi ve onların kendi yaşamları ve yaşadıkları kentsel çevre ile ilgili politik tartışmalara katılmalarını sağlamak için kullanılabilir. Bu çerçevede, her ne kadar, akıllı kentlere yapılan vurgu büyük ölçüde ekonomik büyüme ve küresel bilgi ekonomisindeki rekabetçilik ile ilgili olsa da, akıllı bir toplum ile vatandaşların yerel karar alma süreçlerine katılımı ve etkisi artırılabilir. Diğer bir ifadeyle, gerçek akıllı kent bir tür sanal kamu kültürü oluşturarak, bilgi teknolojilerini demokratik süreçleri geliştirmek için kullanabilir. Ayrıca, gerçek bir akıllı kent ekonomik büyüme ve çevresel sürdürülebilirlik arasında denge kurmaya çalışır. Hollands'ın görüşlerine paralel olarak, Ssekatawa (2016) da, akıllı kent girişimlerinde sosyal içermenin önemini vurgulamakta, bu çerçevede, vatandaş katılımının akıllı kent girişimlerinin planlama ve geliştirme faaliyetlerinin merkezinde olması gerektiğini savunmaktadır. Dünyadaki başarılı ve başarısız akıllı kent örnekleri incelenerek hazırlanan "Akıllı Şehir Yol Haritası" isimli çalışmada da beşeri sermayeye dikkat çekilmektedir. Sözkonusu çalışmada, net bir vizyon, kamu-özel sektör işbirliği, entegre organizasyon, etkin akıllı şehir platformu, vatandaş katılımı, destekleyici teknoloji, risk yönetimi, sosyal kapsayıcılık, proje yaygınlaştırma becerisi ve destekleyici yasal çerçevenin akıllı kente dönüşüm yolculuğunda başarı açısından kritik öneme sahip unsurlar olduğu belirtilmektedir (Deloitte-Vodafone, 2016).

\subsection{Akıllı Kent Kopenhag}

Onuncu yüzyılda küçük bir Viking balıkçı köyü olan Kopenhag, günümüzde Aarhus, Aalborg, Vejle gibi birçok akıllı kente ev sahipliği yapan Danimarka'nın en kalabalık şehri ve aynı zamanda başkentidir (Mortensen vd., 2012). Kentsel çevre ve yaşam kalitesi çok yüksek olan bu kent, Avrupa'nın en yeşil ve aynı zamanda en büyük finans merkezlerinden birisidir. Kopenhag, 2014 yılında, "kentlerin bir yandan insanların yaşam kalitesini yükseltmesi gerektiği, diğer yandan, çevre üzerindeki olumsuz etkilerini azaltması gerektiği" mesajıyla ve "yeşil kentler yaşama uygundur" sloganıyla çevre dostu kentsel yaşama öncülük eden kentleri teşvik etmek için verilen "Avrupa Yeşil Başkenti” ödülünü 
kazanmıştır (Cömertler, 2020). Kent, ayrıca, "Yeşil Ekonomi Lideri” seçilmiş, birçok defa da "Dünyanın En Bisiklet Dostu Kenti" ve "Dünyanın En Yaşanabilir Şehri" unvanıyla ödüllendirilmiştir (The City of Copenhagen, 2020a). Akıllı kent çalışmalarıyla da ön plana çıkan Kopenhag, daha yeşil bir şehir oluşturmak, kentteki yaşam kalitesini artırmak ve iş ortamını iyileştirmek için büyük veri toplama ve kullanımı konusunda dünyanın en iyi planı olarak değerlendirilen Kopenhag Bağlanıyor Projesi ile 2014 yılında "Dünya Akıllı Kentler Ödülü"nü kazanmıştır (Copenhagen Capacity, 2020a). Bu proje kapsamında, kentteki trafik sıkışıklığını, hava kirliliğini ve karbon emisyonlarını azaltmak için cep telefonlarından, otobüslerdeki GPS'lerden, çöp kutularındaki sensörlerden ve kanalizasyon sisteminden gelen büyük veriler kullanılmaktadır (Copenhagen Capacity, 2020b).

Kopenhag'ın en önemli akıllı kent hedefi, 2025 yılına kadar dünyanın ilk nötr karbon başkenti olmaktır. Bu hedefe yönelik olarak hazırlanan İklim 2025 Planı, enerji tüketimi, enerji üretimi, yeşil hareketlilik ve şehir yönetimi olmak üzere, dört önemli alana ilişkin hedefleri ve girişimleri bir araya getiren bütüncül bir plandır. İklim Planı, nötr karbon hedefinin daha iyi bir yaşam kalitesi, inovasyon, yatırım ve istihdam oluşturmak için kaldıraç olarak kullanılması gerektiğini ve hükümet, iş dünyası, bilgi kurumları ve Kopenhaglılar arasında yakın işbirliği yoluyla 2025 yılına kadar nötr karbon hedefine nasıl ulaşılabileceğini açıklamaktadır. Kopenhag kent yönetimi İklim Planı ile, büyüme ve gelişmeyi daha temiz bir hava, daha az gürültü ve daha iyi yaşam kalitesi gibi çevresel faydalarla birleştirmeyi amaçlamaktadır. Bu amaç doğrultusunda, kentin temiz teknoloji şirketleri için uluslararası bir merkez haline gelmesi istenmektedir (City of Copenhagen, 2014, 2012). İlim 2025 Planı'nın yanı sıra, Akıllı Ulaşım Sistemleri Eylem Planı, Eko-metropol Planı, Ajanda 21, Trafik Güvenliği, Geri Dönüşüm Stratejisi, Servis ve Kanal Stratejisi akıllı kenti destekleyen diğer önemli plan ve politikalardır (Ulusoy, 2017). Birleşmiş Milletler'in 2030 Ajandası doğrultusunda ve vizyoner bir bakış açısıyla hazırlanan Kopenhag Sürdürülebilir Kalkınma Amaçları Eylem Planı ise halihazırda kentin en önemli politika dokümanlarından biridir (2030 Ajandası hakkında bkz. United Nations, 2015). Sürdürülebilirliği esas alan kentler için örnek niteliğindeki bu Eylem Planı ile Kopenhag şehir yönetimi, akıllı ve tüm yönleriyle sürdürülebilir bir kentsel gelişme için birbiri ile ilişkili bir dizi politika ve strateji belirlemiştir (City of Copenhagen, 2018).

Akıllı kent gelişiminin politik bir öncelik olarak ele alındığı Kopenhag, günümüzde temiz teknoloji, inşaat ve ulaşım sektörlerinde akıllı kent teknolojilerinin test edildiği ve geliştirildiği yaşayan bir laboratuvar olarak değerlendirilmektedir (Copenhagen Capacity, 2020c). Zira Kopenhag şehir yönetimi kenti daha temiz ve sağlıklı hale getirecek ve daha iyi çalışmasını sağlayacak akıllı kent çözümleri üzerinde proaktif olarak çalışmaktadır. Bu bağlamda, yenilikçi ve sürdürülebilir çözümler üreten yaşayan laboratuvarlar - Kopenhag Çözümleri Laboratuvarı ve Nordhavn Enerji Laboratuvarı akıllı kent çalışmalarında kilit role sahip birimlerdir (The City of Copenhagen, 2020b) (Yaşayan laboratuvarların kentsel sürdürülebilirlik üzerindeki rolü hakkında bkz. Voytenko vd., 2016). Kopenhag Çözümleri Laboratuvarı akıllı kent girişimleri için yabancı şirketler ile Kopenhag Belediyesi arasında köprü görevi üstlenmektedir. Laboratuvar faaliyetlerini beş ana tema altında yürütmektedir (bkz. Çizelge 1). Bu temalar çerçevesinde yürütülen çalışmalar Underbroen, İskandinav Akıllı Kentler Ağı ve Enerji Bloğu gibi şehir laboratuvarlarında geliştirilmekte ve test edilmektedir. Kopenhag'da şehir laboratuvarlarının yanı sıra, birçok alanda verilerin paylaşıldığı platformlar da kurulmuştur. Zira yönetimde şeffaflığın sağlanması ve kentte veriye dayalı yeniliklerin ve büyümenin teşvik edilmesi için Kopenhag Belediyesi veri üretimi ve verilerin açık bir şekilde sunumuna büyük önem vermektedir (Copenhagen Solutions Lab, 2020). 
Çizelge 1. Kopenhag Çözümleri Laboratuvarı faaliyet temaları, şehir laboratuvarları ve veri portalları (Kopenhag Çözümleri Laboratuvarı web sitesinden yararlanılarak yazar tarafından oluşturulmuştur, ayrıntılı bilgi için bkz. Copenhagen Solutions Lab, 2020).

\section{TEMALAR \& FAALIYETLER}

Insanlar ve akışlar İnsanların davranış kalıplarını dikkate alarak daha iyi kentsel alanlar oluşturmak ve kentsel gelişmeyi verilere dayalı olarak daha akıllı ve daha büyük hale getirmek hedeflenmektedir. Laboratuvarda elde edilen veriler ile örneğin, yayalar ve bisikletliler için trafiğin önceliklendirilmesine yönelik çalışmalar desteklenmektedir.

Dijital hizmetler Şehir sakinlerine ve ziyaretçilere daha iyi hizmet sunmak için kentsel alanlarda wifi ve bilgi ekranları gibi iletişim altyapısının kurulması desteklenmektedir. Ayrıca kentlileri ve ziyaretçileri yönlendiren, trafik akışı gibi bilgileri sağlayan dijital hizmetler desteklenmektedir.

\begin{tabular}{ll}
\hline $\begin{array}{l}\text { Veriye dayalı } \\
\text { operasyon ve } \\
\text { denetim }\end{array}$ & $\begin{array}{l}\text { Manuel olarak gerçekleştirilen, bu nedenle de uzun çalışma saatleri ve büyük bütçeler gerektiren } \\
\text { operasyonel görevlerin geliştirilmesi, böylece şehir sakinlerine daha iyi ve daha odaklanmış } \\
\text { hizmetler sunulması desteklenmektedir. }\end{array}$ \\
\hline Çevre ve iklim & $\mathrm{CO}_{2}$ emisyonlarını azaltmanın ve enerji optimizasyonunu sağlamanın yeni yolları araştırımaktadır. \\
\hline Hava kalitesi & $\begin{array}{l}\text { Hava kirliliği hakkında tutarlı bir veri tabanı oluşturmak için, üniversiteler ve şirketler ile işbirliği } \\
\text { içinde, mobil ve sabit sensörler kullanılarak, politika geliştirme ve diğer faaliyetlerin temelini } \\
\text { oluşturacak yeni bilgiler üretilmekte ve test edilmektedir }\end{array}$
\end{tabular}

ŞEHIR LABORATUVARLARI

Sokak Laboratuvarı Cisco, TDC, Citelum ve Kopenhag Çözümleri Laboratuvarı arasında geliştirilen kamu-özel (Street Lab) ortaklığında bir laboratuvardır. Akıllı otopark, atık yönetimi ve hava kalitesinin ölçülmesi gibi alanlarda geliştirilen çözümler test edilmektedir.

Underbroen Geleneksel iş̧̧iliğin modern dijital üretim teknolojileri ile birleştirildiği bir atölye olan ve Maker, BetaLab ve Kopenhag Belediyesinin işbirliği ile kurulan Underbroen küçük işletmelere, şirketlere ve kuruluşlara dijital üretim teknolojileri, tasarım düşüncesi, prototip oluşturma ve ürün fikirlerinin geliştirilmesi hakkında bilgi edinme ve test etme imkanı sağlamaktadır.

İskandinav Akıllı Danimarka, İsveç, Norveç, Finlandiya ve İzlanda olmak üzere beș İskandinav ülkesinden beși Kentler Ağı başkent olmak üzere toplam 14 şehrin (Kopenhag, Stockholm, Oslo, Helsinki, Reykjavik, Aarhus, (Nordic Smart City Vejle, Lyngby, Syddjurs, Bergen, Trondheim, Stavanger, Troms $\varnothing$, Kristiansand, Tampere, Oulu, Network) Espoo, Vantaa, Turku, Malmö) katıldığı bu uluslararası işbirliği projesi ile yaşayan laboratuvarlardan elde edilen deneyimlerin paylaşılması, yaşanabilir ve sürdürülebilir şehirler oluşturmanın ve küresel alanda rekabet edebilmenin yeni yollarının keşfedilmesi hedeflenmektedir.

Enerji Bloğu Kopenhag Belediyesi, Danimarka Teknik Üniversitesi ve bir dizi şirket ile işbirliği içinde oluşturulan,

(Energy Block) Danimarka ve Avrupa programları tarafından finanse edilen bir projedir. Yenilenebilir enerji kaynaklarının gerçek kentsel ortamda kullanım potansiyeli araştırılmaktadır

Akıllı Kentler Lund Üniversitesi, Kopenhag Üniversitesi gibi önemli akademik kurumlar ve enerji şirketleri ile İnubatörü işbirliği içinde bir grup İskandinav kentinin ortak olduğu proje kapsamında geleceğin enerji (Smart Cities sistemleri ve yeni yeşil çözümler üzerinde çalışılmaktadır. 6.5 milyon $€$ bütçeli proje bölgeler arası Accelerator) işbirliğini destekleyen AB programı Interreg- $\varnothing \mathrm{KS}$ tarafından finanse edilmektedir.

\section{VERI PORTALLARI}

Açık Veri Portalı (Open Data DK)

Şehirler için Seçin (Select for Cities)
Ulaşım, trafik, çevre, sağlık, eğitim, kültür, spor, ekonomi, finans, nüfus, toplum, enerji, tarım, balıkçılık, ormancılık, gıda gibi birçok alanda veri paylaşımaktadır.

Kopenhag, Anvers ve Helsinki şehirleri tarafından başlatılan bu program ile yeni ve yenilikçi bir nesnelerin interneti platformu oluşturmak amaçlanmaktadır. Avrupa Birliği Horizon 2020 projesi olan program 5.6 milyon €'luk bütçesi ile şirketlere prototip geliştirme ve bunları gerçek dünya koşullarında test etme konusunda finansman sağlamaktadır.

Şehir Veri Alışverişi Özel sektör ve kamu sektörü arasında veri alışverişi olanaklarını incelemeyi amaçlayan proje

(City Data

Exchange) Kopenhag Belediyesi, Başkent Bölgesi, CLEAN (Danimarka Temiz Teknoloji Kümesi) ve Hitachi arasında kurulan bir işbirliğidir. Şehir Veri Alışverişi projesi ile büyük, küçük ve orta ölçekli şirketlerin, yeni kurulan şirketlerin, üniversitelerin ve kamu sektörünün çeşitli bilgi kaynaklarını birleştirerek işbirliği yapması beklenmektedir. 
2025 Iklim Planı ile uyumlu olarak, Kopenhag'da kentsel yaşam kalitesini yükseltmeye ve sosyoekonomik-çevresel sürdürülebilirliğe katkı sağlamaya yönelik Çizelge 1 'de açıklanan akıllı kent uygulamalarının yanı sıra birçok "sürdürülebilir" ve "akıllıca" kentsel çözüm üretilmiştir (bkz. Çizelge 2). Bisiklet ulaşımı, entegre ulaşım sistemi, stratejik şehir planlaması, mavi dönüşüm, su kaynaklarının daha iyi yönetimi, bölgesel ısıtma ve soğutma, rüzgar enerjisi, atıkların geri dönüşümü ve sürdürülebilir binalar bu çözümlerin başlıcalarını oluşturmaktadır (City of Copenhagen, 2014).

Çizelge 2. Kopenhag'da sürdürülebilir kentsel çözümler ("Sürdürülebilir Şehirler için Kopenhag Çözümleri" raporundan yararlanılarak yazar tarafından oluşturulmuştur, ayrıntılı bilgi için bkz. City of Copenhagen, 2014).

\section{SÜRDÜRÜLEBiLIR KENTSEL ÇÖZÜMLER}

\begin{tabular}{ll}
\hline Bisiklet ulaşımı & Bütün kenti kapsayan bisiklet yolları ağı, bisiklet köprüleri, hızı bisiklet yolları, taşıt yollarına paralel \\
& bisiklet şeritleri, bisiklet park yerleri, park ve rekreasyon alanları boyunca bisikletler için yeşil \\
& rotalar, aileler için otomobile alternatif kargo bisikletleri, bisikletçiler için güvenli kavşaklar, bisiklet \\
& ulaşımının toplu taşıma sistemine entegrasyonu, bisikletçilerin durmadan seyahat edebilmeleri için \\
& trafik ışıklarında yeşil dalga sistemi (yeşil ışığın $20 \mathrm{~km} /$ saat hıza ayarlanması).
\end{tabular}

Entegre ulaşım Yolcuların farklı modlar arasında sorunsuz bir şekilde hareket etmesini sağlamak için otobüs, tren sistemi ve metro hizmetlerinin fiziksel ve çevrimiçi entegrasyonu, bisikletlerin toplu ulaşıma entegrasyonu.

Eski liman alanında Araştırmacılar, akademisyenler, plancılar, mimarlar, mühendisler, belediye ve özel sektör gerçekleştirilen kuruluşları arasındaki işbirliği ile yenilikçi çözümlerin üretilmesi: kentsel tasarım ve atıksu mavi dönüşüm yönetiminin entegrasyonu. Kanalizasyon sisteminin modernizasyonu, deniz suyu temizleme programı ile limandaki su kalitesinin iyileştirilmesi, yağmur suyunun yönlendirilmesi, halka açık liman banyoları ve rekreasyon alanlarının oluşturulması ile liman alanının mavi bir kamusal alana dönüştürülmesi.

Su kaynaklarının Su basıncını daha iyi düzenleyen akılı sistem yönetimi ile yeraltı su kaynaklarının korunması, kaçak daha iyi yönetimi tespit teknolojisi ile içme suyu temin sistemindeki kayıpların sınırlandırılması, su sayaçları ve fiyatlandırma mekanizmalarıyla savurgan tüketimin azaltılması.

Rüzgâr enerjisi 2025 yılına kadar, kentte tüketilen elektriğin tamamının rüzgar santrallerinden sağlanmasına yönelik çalışmalar. Bunun için yüksek teknoloji kullanımı, Middelgrunden'deki ilk rüzgar çiftliğinin halka arzı ile topluluk sahipliliğinin oluşturulması ve yeni tribünlerin inşası, bilinçlendirme kampanyaları ile "arka bahçemde değil" tutumunun üstesinden gelinmesi.

\begin{tabular}{ll}
\hline Atıkların geri & Kaynak ve Atık Yönetim Planı 2018'de yansıtılan vizyon ve genel hedefler doğrultusunda, 2050 \\
dönüşümü & yılına kadar sıfır atık kent olmaya yönelik çalışmalar. Atıkların bir kaynak olarak ele alınması, bu \\
& çerçevede, atık üretiminin azaltılması, doğrudan yeniden kullanımın artırılması, geri dönüşümün \\
& artırılması, yakmanın azaltılması.
\end{tabular}

Bölgesel ısıtma

Kombine Isı ve Güç teknolojisinin kullanımı ile elektrik üretim sürecinde kaybolan ısı enerjisinin yakalanması ve yeniden kullanılması. Bölgesel ısıtma ağı ile ısı enerjisinin şehir içinde daha verimli bir şekilde dağıtılması. Biyokütle gibi yenilenebilir yakıtların entegrasyonu ile bölgesel ısıtma ağındaki karbon yoğunluğunun azaltılması.

Bölgesel soğutma Kısmen soğuk deniz suyuyla soğutulmuş suyun merkezi bir şekilde üretimi ve yer altı yalıtımlı boru hatları ile endüstriyel-ticari binaların kullanımına sunulması.

Sürdürülebilir Enerji, su ve diğer kaynakların verimli kullanımı; atıkların, kirliliğin ve çevresel bozulmanın binalar azaltılması; çalışan sağlığının korunması ve verimliliğinin artırılması için yüksek kaliteli iç mekan ikliminin sağlanması; binaların ekonomik fizibilitesi üzerine yeni fikirlerin geliştirilmesi; kullanım ömrü maliyetlerine ve malzeme maliyetlerine odaklanılması prensipleri doğrultusunda Yeşil Bina uygulamaları. Bu çerçevede verimli bina kabuğu uygulaması, LED aydınlatmanın ve güneş pillerinin kullanımı, yeşil çatılar ve küçük bahçelerin oluşturulması, yağmur suyunun toplanması ve yeniden kullanılması, atık geri dönüşümü için konteynırların kullanımı, dış mekanda yeşil alanların oluşturulması. Eski yapılardaki güçlendirmelerde, ayrıca, pencerelerin yenilenmesi, duvar, kapı, çatı, zemin ve su borularının yalıtımının sağlanması.

Stratejik şehir Transit Odaklı Gelişme Yaklaşımı ve 1947'de kabul edilen (ilerleyen zamanlarda güncellenen) planlaması Parmak Planı (Finger Plan) kentin gelişimini yönlendiren en önemli planlama araçlarıdır. Parmak Planı kararlarına göre, kent tren ve ana yol rotalarını takip eden ve aralarında açık alanlar bulunan beş "parmak" boyunca genişlemektedir (bkz. Şekil 1). Kentsel gelişmenin yalnızca şehir parmaklarında gerçekleştirilmesine izin veren tarihsel planlama ilkesi halen yürürlükte olup, parmaklar arasındaki alanlar belediye sınırları boyunca yeşil kamalar olarak korunmaktadır. Cömertler (2020), böylece, bir yandan gereksiz kentsel yayılmanın önüne geçildiğini, bir yandan da 
Kopenhaglılara geniş rekreasyon alanları sağlandığını belirtmektedir.

Akıllı kent kavramının ortaya çıkışından çok daha önceki bir dönemde hazırlanan bu "akıllıca" ve "sürdürülebilir" planın yanı sıra, kentsel gelişmenin finanse edilmesi için stratejik saha hazırlıkları, yenilikçi ve sürdürülebilir çözümler için paydaşlarla ortaklıklar ve kentlilerle diyalog Kopenhag'da stratejik şehir planlamasının diğer önemli unsurlarıdır.

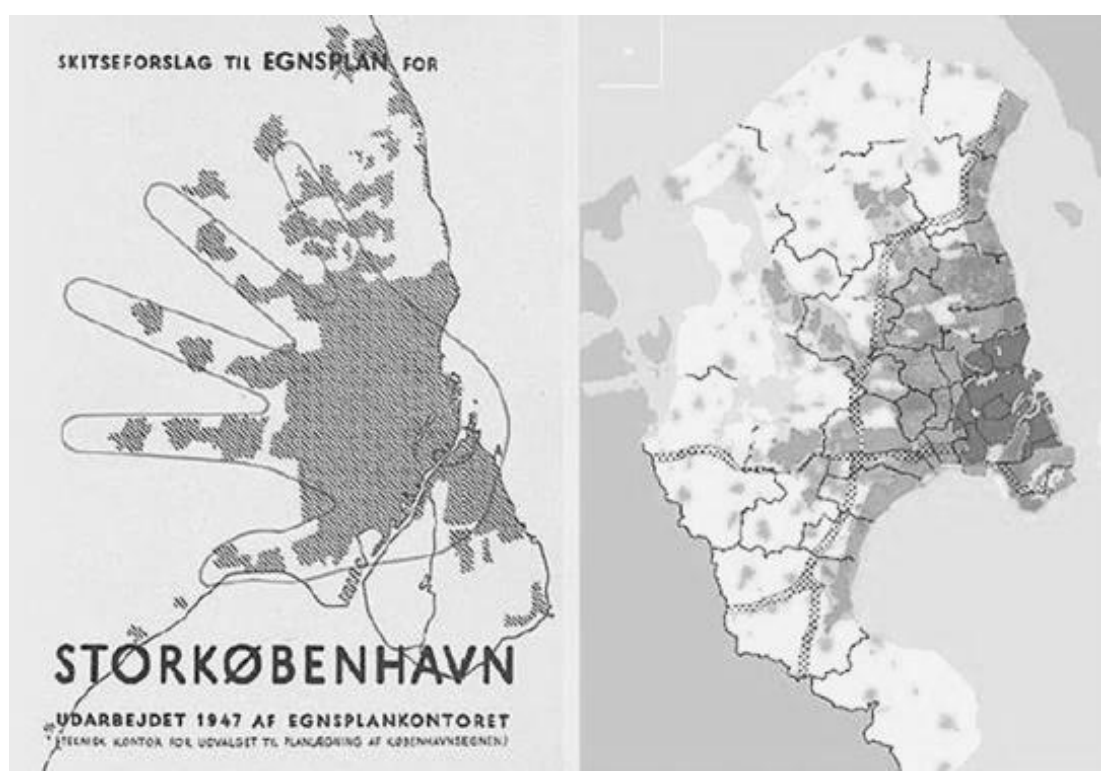

Şekil 1. Kopenhag'ın ilk Parmak Planı ve 2007'deki revizyonu (Danish Ministry of the Environment, 2012, s: 159)

Literatürde, Kopenhag'da akıllı kent gelişmelerini destekleyen uzun vadeli ve sıkı bir iklim gündeminin olması, net bir akıllı kent vizyonunun geliştirilmiş olması, birimler arası koordinasyon sağlayan bir yapının kurulmuş olması, projelerin vizyona uyumunun takip edilebilmesi, etkin paydaş katılımının desteklenmesi, güçlü eğitim ve araştırma kurumlarının ve inovasyon merkezlerinin olması, özel sektör katılımının teşvik edilmesi Kopenhag'ın akıllı kente dönüşüm sürecinde ön plana çıkan başarılı yönleri olarak değerlendirilmektedir (Deloitte-Vodafone, 2016).

\subsection{Kopenhag'da Akıllı Kent Teknolojilerinin Kullanımı ve Sürdürülebilir Kentsel Çözümler ile Elde Edilen Çevresel, Sosyal ve Ekonomik Kazanımlar}

Nötr karbon başkent olma hedefi ve bu hedef doğrultusunda gerçekleştirilen çalışmalar Kopenhag'ı akıllı ve sürdürülebilir bir kent olma yönünde desteklemektedir. Örneğin, Kopenhag Çözüm Laboratuvarı uygulamaları sayesinde kentte $\mathrm{CO}_{2}$ salınımı 180 bin ton azaltılmış, su tüketiminde 5,5 milyon $\mathrm{m}^{3}$ su tasarrufu sağlanmış, akıllı trafik çözümleriyle araçta geçirilen 2,4 milyon saat insanlara geri kazandırımış, 1,7 milyon litre yakıt tasarrufu elde edilmiş ve bisiklet hırsızlığında \%50 azalma meydana gelmiştir. Bu çevresel ve sosyal faydaların yanı sıra şehri ziyaret eden turist sayısında \%1'lik artış sağlanırken, 104 milyon Euro değerinde iş fırsatı oluşturulmuştur (Deloitte-Vodafone, 2016: 9899). Ayrıca, Ramboll gibi özel şirketlerle ve Kopenhag Üniversitesi, Aalborg Üniversitesi, Danimarka Teknik Üniversitesi gibi kurumlarla işbirliği içinde oluşturulan Kopenhag Bağlanıyor sistemi tam olarak uygulandığında 4.4 milyar Danimarka Kronu ekonomik fayda elde edilmesi beklenmektedir (The City of Copenhagen, 2020b).

Kentsel sürdürülebilirliğe odaklanan akıllı kent uygulamaları Kopenhag'ı yaşamak, çalışmak ve iş yapmak için avantajlı kılmaktadır. Kopenhag Kapasitesi verilerine göre, Hitachi, Cisco, Ramboll, Siemens, IBM ve Kopenhag Temiz Teknoloji Grubu gibi çok sayıda yerli ve çokuluslu akıllı şehir ortağı olan Kopenhag'ın hızla büyüyen akıllı şehir endüstrisi içinde 250 şirket akılı kent faaliyetlerine katılmaktadır (Copenhagen Solutions Lab, 2020). Ayrıca, yatırım yapmanın avantajlı ve kolay olduğu Kopenhag büyük ve küçük teknoloji firmalarına, bankalara, finans kuruluşlarına ve lojistik firmalarına ev sahipliği yapmaktadır.

Kopenhag'da yeni, yeşil ve akıllı teknolojiler kullanılarak geliştirilen entegre ulaşım sistemi, rüzgar enerjisi, atıkların geri dönüşümü, sürdürülebilir binalar gibi sürdürülebilir şehir çözümleri, yukarıda 
verilen örneklerin yanı sıra, çok geniş bir yelpazede pek çok çevresel, sosyal ve ekonomik fayda sağlamıştır. Bu kazanımlar Çizelge 3'de özetlenmektedir.

Çizelge 3. Kopenhag'da çevresel, sosyal ve ekonomik kazanımlar ("Sürdürülebilir Şehirler için Kopenhag Çözümleri" raporundan yararlanılarak oluşturulmuştur, bkz. City of Copenhagen, 2014).

\begin{tabular}{lll}
\hline $\begin{array}{l}\text { KENTSEL } \\
\text { ÇÖZÜMLER }\end{array}$ & ÇEVRESEL KAZANIMLAR & SOSYAL KAZANıMLAR \\
\hline Bisiklet ulaşımı & $\bullet$ Gürültünün azalması & • Bisiklet kullananların \% \\
& $\bullet$ Hava kirliliğinin azalması & $88^{\prime}$ ine göre, işe gitmenin en \\
& $\bullet \mathrm{CO}_{2}$ azalması & hızlı ve pratik yolu olması \\
& & - Yeni iş imkânları \\
& & - Şehir hayatının gelişmesi
\end{tabular}

EKONOMIK KAZANIMLAR

\begin{tabular}{ll} 
& \\
& \\
\hline $\begin{array}{l}\text { Entegre ulaşım } \\
\text { sistemi }\end{array}$ & $\begin{array}{l}\text { Toplu taşıma araçlarıyla } \\
\text { artması, böylece özel araç } \\
\text { kullanımının azalması }\end{array}$
\end{tabular}

- Daha hızlı, daha güvenli, daha sağııkı ve daha az stresli yolculuklar

- Bisiklet ile entegre toplu taşımanın seyahatin en hızlı, en ucuz,en uygun yolu olması

- Kopenhag'ın dünyanın en yaşanabilir şehirlerinden biri olarak ün yapması

\begin{tabular}{ll}
\hline Eski liman & - Sel riskinin azalması \\
alanında & - Daha fazla ve çeşitli flora ve \\
gerçekleştirilen & faunanın alana geri dönüşü \\
mavi dönüşüm &
\end{tabular}

- Kent sakinleri ve ziyaretçiler için kentin kalbinde yüzme, yelken ve balık avlama gibi rekreasyon imkanları

- Hemen hemen bütün Kopenhaglılar için, yeşil veya mavi bir rekreasyon alanına veya bir parka 10 dakikadan az bir yürüme mesafesinde yaşama imkanı

- Bölge sakinlerinin artan aidiyet duygusu ve övüncü
- Ulaşım maliyetlerinde düşme (Otomobile kıyasla her km için $0,16 €$ tasarruf)

- Daha az yolculuk süresi ve trafik sıkışıklığı ile artan ekonomik verimlilik

- Pedal çevrilen km başına $0.77 €^{\prime}$ luk sağlık bakım maliyetlerinde düşüş

- Bisiklet kullanımı ile sağlık harcamalarında 230 milyon €'luk tasarruf

- Trafikte tıkanıklık ve kayıp saatlerde azalma

- Azalan trafik sıkışıklığının, hızlı ve güvenilir yolculuk sürelerinin çalışma hayatı açısından kenti cazip kılması
- Belediyeler ve tedarik şirketleri arasındaki işbirliğinin yeraltı sularının korunmasına yönelik ilgiyi teşvik etmesi
- Liman alanlarının dönüşümü ile iş dünyası ve pazarın canlanması

- Liman alanındaki emlak fiyatlarında \%50 ile \%100 arasında değişen artışlar

- Yatırım potansiyelinin yükselmesi

- Iş̧ imkânlarının artmas

- Artan yaşanabilirliğin ekonomik büyümeye katkıda bulunması

\begin{tabular}{|c|c|}
\hline $\begin{array}{l}\text { Su kaynaklarının } \\
\text { daha iyi yönetimi }\end{array}$ & $\begin{array}{l}\text { - Gürültünün azalması } \\
\text { - Su hizmetleri için enerji } \\
\text { tüketiminin azalması } \\
\text { - Tuzdan arındırma gibi enerji } \\
\text { yoğun çözümlerden } \\
\text { kaçınılması } \\
\text { - Şişelenmiş su talebinin } \\
\text { azalması }\end{array}$ \\
\hline Rüzgâr enerjisi & $\begin{array}{l}\text { - Karbon azaltma hedeflerine } \\
\text { ulaşılmasına katkı sağlaması } \\
\text { - Middelgrunden rüzgâr } \\
\text { santrali ile yılda } 89 \text { milyon } \\
\text { kW elektrik üretiminin } \\
\text { sağlanması ve } \\
\text { - } \mathrm{SO}_{2} \text { emisyonunun } 232 \text { ton } \\
\text { - } \mathrm{NO} \text { emisyonunun } 208 \text { ton } \\
\text { - } \mathrm{CO}_{2} \text { emisyonunun } 68.000 \text { ton } \\
\text { - toz ve klinkerlerin } 4.400 \\
\text { ton azaltılması }\end{array}$ \\
\hline
\end{tabular}

- Aşağıdakiler yoluyla uzun vadeli maliyetlerin azalması:

- Daha düşük enerji kullanım

- Mevcut boru ağının daha az sıklıkta değiştirilmesi

- Daha iyi izleme ve onarım

- Daha yüksek su verimliliği sayesinde daha düşük üretim maliyetleri

- İklim değişikliği hedeflerine ulaşmada toplumsal taahhüdün sağlanması

- Yeni iş imkânlarının doğması
- Rüzgâr çiftliği satışından elde edilen karın kentteki diğer projelere kazandırılması

- 350'den fazla şirket ile milyarlarca €'luk hacme ulaşan rüzgâr türbini endüstrisiyle yeşil ekonomiye katkı

- Düşük işletme maliyetleri 


\begin{tabular}{|c|c|c|c|}
\hline $\begin{array}{l}\text { Atıkların geri } \\
\text { dönüşümü }\end{array}$ & $\begin{array}{l}\text { - Yenilenemeyen kaynaklar } \\
\text { üzerindeki baskının azalması } \\
\text { - Atıkların yakılması ile oluşan } \\
\text { sera gazı emisyonlarının } \\
\text { azalması } \\
\text { - Üretim sürecindeki enerji } \\
\text { tüketiminin azalması } \\
\text { - Saf kaynakların } \\
\text { madenciliğinden } \\
\text { kaynaklanan sera gazı } \\
\text { emisyonlarının ve kirliliğin } \\
\text { azalması } \\
\text { - Kapalı kaynak döngüsünün } \\
\text { oluşturulması }\end{array}$ & $\begin{array}{l}\text { - Kentlilerin değişime dâhil } \\
\text { edilmesi ve güçlendirilmesi } \\
\text { - Kirleticilerin zararlı } \\
\text { emisyonlarının önlenmesi } \\
\text { - Topluluk inşası } \\
\text { - Artan çevre bilinci } \\
\text { - Atıkların ayrıştırılmasının } \\
\text { sosyal bir norma dönüşmesi }\end{array}$ & $\begin{array}{l}\text { - Çevreye zarar vermeden } \\
\text { ekonomik verimliliğin artması } \\
\text { - Ekonomik ve çevresel açıdan } \\
\text { sürdürülebilir bir pazarın } \\
\text { oluşturulması }\end{array}$ \\
\hline Bölgesel ısıtma & $\begin{array}{l}\text { - Tekil gaz kazanlarından } \% 40 \\
\text { daha düşük } \mathrm{CO}_{2} \text { emisyonu } \\
\text { - Birincil enerji tüketiminin } \\
\text { tekil kazanlara kıyasla } \% 70 \\
\text { oranında azalması }\end{array}$ & $\begin{array}{l}\text { - Bölgesel ısıtma sistemi için } \\
\text { gerekli şebeke altyapısının } \\
\text { geliştirilmesi sürecinde yeni } \\
\text { istihdam olanakları } \\
\text { - Bölgesel ısıtmanın tüm } \\
\text { ekonomik faydalarının } \\
\text { tüketicilere iade edilmesi } \\
\text { - Bölgesel ısıtma sistemine } \\
\text { katılma ve sabit altyapı } \\
\text { maliyetlerinin paylaşılması ile } \\
\text { ısınma ücretinin tüm } \\
\text { tüketicilerin yararına } \\
\text { azalması }\end{array}$ & $\begin{array}{l}\text { - Aynı anda ısı ve güç üreterek } \\
\text { \% } 94 \text { 'e varan yüksek yakıt } \\
\text { verimliliği ile daha az yakıt } \\
\text { ihtiyacı } \\
\text { - } \mathrm{CO}_{2} \text { ve diğer emisyonların } \\
\text { çevresel maliyetleri dikkate } \\
\text { alındığında en uygun } \\
\text { maliyetli ısıtma olması } \\
\text { - Yeni iş alanlarının oluşması }\end{array}$ \\
\hline Bölgesel soğutma & $\begin{array}{l}\text { - Geleneksel soğutmaya } \\
\text { kıyasla \%70 oranında } \mathrm{CO}_{2} \\
\text { azalması } \\
\text { - Kentsel ısı adası etkisinin } \\
\text { azalması } \\
\text { - Elektrik talebinde azalma } \\
\text { - Gürültünün azalması }\end{array}$ & $\begin{array}{l}\text { - Lejyoner hastalığı gibi sağlık } \\
\text { risklerinin çoğunun ortadan } \\
\text { kalkması } \\
\text { - Artan enerji güvenliği } \\
\text { - Geleneksel soğutma } \\
\text { sistemleri yerine çatı terasları } \\
\text { - Mimari estetik kalitenin } \\
\text { korunması, güzel bir kent } \\
\text { kimliğinin zarar görmemesi }\end{array}$ & $\begin{array}{l}\text { - Enerji ithalatı harcamalarında } \\
\text { azalma }\end{array}$ \\
\hline $\begin{array}{l}\text { Sürdürülebilir } \\
\text { binalar }\end{array}$ & $\begin{array}{l}\text { - Yenilenmiş eski binalarda ve } \\
\text { yeni inşa edilmiş } \\
\text { sürdürülebilir binalarda } \mathrm{CO}_{2} \\
\text { emisyonunun ve enerji } \\
\text { tüketiminin azalması } \\
\text { - İklim dostu girişimlere ilham } \\
\text { vermesi } \\
\text { - Çevresel etkinin azalması }\end{array}$ & $\begin{array}{l}\text { - Mevcut binaların korunması } \\
\text { ile kentsel belleğin } \\
\text { sürdürülmesi } \\
\text { - Yaşam kalitesinin artması ve } \\
\text { dışa göçün önlenmesi } \\
\text { - İyileştirilmiş iç mekân iklimi } \\
\text { ile insan sağlığı üzerinde } \\
\text { pozitif etki } \\
\text { - Binaların geleceğe hazır } \\
\text { olması }\end{array}$ & $\begin{array}{l}\text { - Gayrimenkul değerlerinin } \\
\text { artması } \\
\text { - Bina güçlendirme } \\
\text { yatırımlarının inşaat } \\
\text { sektörüne katkısı } \\
\text { - Binalara yapılan kamu } \\
\text { yatırımları ile daha fazla özel } \\
\text { yatırımın çekilmesi } \\
\text { - Yaşam döngüsü } \\
\text { maliyetlerinde azalma }\end{array}$ \\
\hline $\begin{array}{l}\text { Stratejik şehir } \\
\text { planlaması }\end{array}$ & $\begin{array}{l}\text { - Yüksek kalite toplu taşıma } \\
\text { ve bisiklet ulaşımı ile } \mathrm{CO}_{2} \\
\text { emisyonlarının azalması } \\
\text { - Kompakt karma kullanım ile } \\
\text { arazi ve ulaşım talebinin } \\
\text { azalması } \\
\text { - Yeni yeşil alanlarla kentin } \\
\text { daha yaşanabilir olması }\end{array}$ & $\begin{array}{l}\text { - Otomobillerin baskın } \\
\text { olmadığı canlı kentsel alanlar } \\
\text { ile sosyal etkileşimin teşviki } \\
\text { - Metro ile kolaylıkla } \\
\text { erişilebilen bölgesel yeşil } \\
\text { alanlar ile yaşam kalitesinin } \\
\text { yükselmesi } \\
\text { - Yerel parklar ve cep parkları } \\
\text { ile artan spor ve sosyal } \\
\text { aktiviteler } \\
\text { - Temiz kanalların kente yeni } \\
\text { bir kimlik kazandırması }\end{array}$ & $\begin{array}{l}\text { - İşletmeler, turistler ve kent } \\
\text { sakinleri için Kopenhag'ın } \\
\text { çekiciliğinin artması }\end{array}$ \\
\hline
\end{tabular}




\section{Sonuç}

Kentleşmeyle birlikte gelişen çevre sorunları karşısında kentsel sürdürülebilirliğin sağlanması ve yaşam kalitesinin yükseltilmesi için yirminci yüzyılda pek çok model ve yaklaşım ortaya konulmakla birlikte, bu yaklaşımlar bütünüyle başarılı olamamış ve yüzyılın sonlarına doğru yeni teknolojilerin kullanılmasına odaklanan yeni modeller ortaya çıkmıştır. Bu süreçte, teknolojinin yanı sıra insana ve çevreye de odaklanan "akıllı kentler" bu modellerin kapsayıcısı olmuştur. Günümüzde, artık akıllı kentler bir zorunluluk olarak değerlendirilmektedir. Bu bağlamda, dünya genelinde akıllı kent uygulamalarına giderek daha çok ilgi gösterilmektedir. Ancak bütüncül bir ele alıştan uzak, salt teknolojiye odaklanan şehirlerde akıllı kente dönüşüm başarısızıkla sonuçlanabilmektedir. Zira başarılı bir dönüşüm için teknoloji önemli bir araç olmakla birlikte, tek başına yeterli değildir. Dolayısıyla akıllı kent teknolojilerinin amaç değil, kentsel sürdürülebilirliği sağlamada faydalı bir araç olarak değerlendirildiği başarılı akıllı kentler, akıllı kent uygulamalarında görece başlangıç aşamasında olan diğer kentler için yol gösterici niteliktedir. Bu görüşten hareketle, bu çalışmada akıllı kentlerdeki çevresel, sosyal ve ekonomik sürdürülebilirlik meselesi Kopenhag kenti örneğinde incelenmiştir.

Araştırmanın bulgularına göre, bugüne kadar sürdürülebilir kentleşme ve yaşam kalitesi çerçevesinde, uluslararası prestije sahip birçok ödül ve unvanla onurlandırılan Kopenhag'da akıllı ve sürdürülebilir gelişme politik bir öncelik olarak ele alınmaktadır. Bu bağlamda akıllı kent vizyonunun temelini oluşturan İklim 2025 Planı, ülkeler için dahi yasal bağlayıcılığı olmamasına rağmen şehir yönetiminin vizyoner bir bakış açısıyla yaklaşarak, 2030 Ajandası doğrultusunda hazırladığı Kopenhag Sürdürülebilir Kalkınma Amaçları Eylem Planı, kentin dijital altyapısını kuran Kopenhag Bağlanıyor Projesi ve akıllı kent girişimleri için yabancı şirketler ile Kopenhag Belediyesi arasında köprü görevi üstlenen Kopenhag Çözümleri Laboratuvarı akıllı ve tüm yönleriyle sürdürülebilir bir kentsel gelişmeyi destekleyen kilit unsurlardır. Kopenhag'da açık veri, akıllı ulaşım ve akıllı otopark gibi konularda ortaya konulan akıllı kent çözümlerinin bir kısmı kamu-özel sektör ortaklı̆ı̆nda kurulan, bir kısmı çok uluslu olan ve bir kısmı Avrupa fonları tarafından desteklenen şehir laboratuvarlarında geliştirilmekte ve test edilmekte olup, kent bir bütün olarak temiz teknoloji, inşaat ve ulaşım sektörlerinde akıllı kent teknolojilerinin test edildiği ve geliştirildiği yaşayan bir laboratuvar olarak değerlendirilmektedir.

Kopenhag'da bisiklet ulaşımı, entegre ulaşım sistemi, mavi dönüşüm ve stratejik şehir planlaması gibi akıllıca planlama yaklaşımları ve akıllı kent teknolojilerinin kullanılması ile çevresel sürdürülebilirlik bağlamında çok çeşitli kazanımlar gerçekleşmiştir. Bu kazanımların başlıcaları $\mathrm{CO}_{2}$ ve diğer kirletici ve zararlı emisyonların azalması, hava kirliliğinin, sel riskinin ve gürültünün azalmasıdır. Yenilenen liman alanında daha fazla ve çeşitli flora ve faunanın gelişmesi, şişelenmiş su talebinin azalması, elektrik talebinin azalması, yenilenemeyen kaynaklar üzerindeki baskının azalması, üretim süreçlerindeki enerji tüketiminin azalması, binalarda enerji tüketiminin azalması, kentsel ısı adası etkisinin azalması, yeni yeşil alanlar ile kentin daha yaşanabilir hale gelmesi, dönüşüm faaliyetleri ve kompakt karma kullanım ile arazi ve ulaşım talebinin azalması, gereksiz kentsel yayılmanın önüne geçilmesi çevresel sürdürülebilirlik bağlamında kentin diğer kazanımlarını oluşturmaktadır.

Kentte sürdürülebilir çözümlerin ve akıllı kent teknolojilerinin kullanılması ile sosyal sürdürülebilirlik bağlamında da pek çok kazanım gerçekleşmiştir. Bu kazanımlar özetle, iş yerine daha hızlı, daha güvenli, daha sağııkı, daha ucuz ve daha az stresli bir şekilde ulaşım imkanı, kent merkezinde yüzme, yelken ve balık avlama gibi rekreasyon imkanları, yeşil ya da mavi bir rekreasyon alanına yürüme mesafesinde erişim imkanı, canlı kentsel alanlar ile sosyal etkileşimin teşvik edilmesi, yerel parklar ve cep parkları ile artan spor aktiviteleri ve sosyal faaliyetler, yaşam kalitesinin artması, dışa göçün önlenmesi, kentlilerin artan aidiyet duygusu ve övüncü, topluluk inşası, artan çevre bilinci, sağıık risklerinin azalması, bölgesel ısıtma sistemi ile elde edilen ekonomik faydaların tüketicilere iadesidir.

Öte yandan, ekonomik sürdürülebilirlik bağlamında kentin başlıca kazanımları rüzgâr türbini endüstrisi ile yeşil ekonominin güçlenmesi, enerji ithalatı harcamalarının azalması, bisiklet kullanımı ile ulaşım maliyetlerinin azalması ve gayrimenkul değerlerinin artmasıdır. Ayrıca, yolculuk sürelerinin kısalması ile ekonomik verimliliğin yükselmesi, sağlık harcamalarının azalması, liman alanlarının dönüşümü ile iş dünyası ve pazarın canlanması, yatırım potansiyelinin yükselmesi, su kaynaklarının daha iyi yönetimi ile uzun vadeli maliyetlerin azalması, bina güçlendirme yatırımları ile inşaat 
sektöründe yaşanan gelişmeler ve binalara yapılan kamu yatırımları ile daha fazla özel yatırımın çekilmesi kentin diğer önemli ekonomik kazanımları olmuştur.

Sonuç olarak, bilgi teknolojileri, temiz enerji teknolojileri ve yenilikçi ulaşım teknolojilerinin kullanıldığı Kopenhag'da, sürdürülebilirlik ekseninde geliştirilen akıllıca planlama çözümleri ve akıllı kent uygulamaları ile çevre ve yaşam kalitesinin iyileştirildiği, hizmet sunumunun iyileştirildiği, şehir sakinlerine ve ziyaretçilerine daha fazla çevre dostu seçenekler sunulduğu ve ekonomik büyümeye katkı sağlandığı, bu çerçevede, kentin "Yeni Kentsel Gündem" raporunda geliştirilen "Çevresel Olarak Sürdürülebilir ve Dirençli Kentsel Gelişme" hedefi bağlamında diğer kentler için örnek teşkil ettiği görülmektedir. Kopenhag şehir yönetiminin akıllı kente dönüşüm sürecinde net bir akıllı kent vizyonu belirleyerek; teknolojiden yararlanarak; araştırma kurumlarının, inovasyon merkezlerinin ve özel sektörün desteğini alarak; yanı sıra kurduğu uluslararası ortaklıklardan ve Avrupa Birliği fonlarından da beslenerek; sosyo-ekonomik-politik ve çevresel boyutta ortaya koyduğu bütünsel, yenilikçi, entegre, proaktif ve uzun vadeli plan, politika ve uygulamalar yoluyla; gelecek nesillerin kendi intiyaçlarını karşılayabilme yeteneğine engel olmayacak şekilde sosyal, ekonomik ve çevresel sürdürülebilirlik arasında denge kurmaya çalıştığını söylemek mümkündür. Ifade edilen bu hususlar, akıllı ve sürdürülebilir bir kente dönüşmek isteyen diğer şehirlerin alması gereken temel derslerdir. Sonraki çalışmalarda, Kopenhag'daki akıllı kent uygulamalarının mekânsal planlama çalışmaları içinde daha ayrıntılı bir şekilde ele alınması literatürün gelişmesine katkıda bulunacaktır.

\section{Teşekkür ve Bilgi Notu}

Makalede, ulusal ve uluslararası araştırma ve yayın etiğine uyulmuştur. Çalışmada etik kurul izni gerekmemiştir.

\section{Kaynaklar}

Ahvenniemi, H., Huovila, A., Pinto-Seppa, I. ve Airaksinen, M. (2017). What are the Differences between Sustainable and Smart cities? Cities, 60, 234-245.

Albino, V., Berardi, U. ve Dangelico, R. (2015). Smart Cities: Definitions, Dimensions, Performance, and Initiatives. Journal of Urban Technology, 22(1), 3-21.

Anagnostopoulos, T., Zaslavsky, A., Kolomvatsos, K., Medvedev, A., Amirian, P., Morley, J. ve Hadjieftymiades, S. (2017). Challenges and Opportunities of Waste Management in loTenabled Smart Cities: A Survey. IEEE Transactions on Sustainable Computing, 2(3), 275-289.

Anthopoulos, L. G. (2017). Understanding Smart Cities: A Tool for Smart Government or an Industrial Trick? Springer International Publishing.

Bernardo, M. R. M. (2017). Smart City Governance: From E-government to Smart Governance. Carvalho LC (ed.) Handbook of Research on Entrepreneurial Development and Innovation within Smart Cities (290-326). Hershey, PA: IGI Global.

Calvillo, C., Snchez-Miralles, A. ve Villar, J. (2016). Energy Management and Planning in Smart Cities. Renewable and Sustainable Energy Reviews, 55(1), 273-287.

City of Copenhagen. (2018). The Capital of Sustainable Development, The City of Copenhagen's Action Plan for the Sustainable Development Goals. City of Copenhagen Department of Finance.

City of Copenhagen. (2014). Copenhagen Solutions for Sustainable Cities. City of Copenhagen.

City of Copenhagen. (2012). CPH 2025 Climate Plan. A Green, Smart and Carbon Neutral City. City of Copenhagen.

Cocchia, A. (2014). Smart and Digital City: A Systematic Literature Review. Dameri, R., RosenthalSabroux C. (ed.) Smart City. Cham: Springer, 13-43.

Copenhagen Capacity. (2020a). Copenhagen Connecting. Erişim Adresi (09.08.2020): http://copenhagenconnecting.com/statements-about-copenhagen-connecting-from-danishknowledge-institutions-copenhagen-connecting-were-awarded-1-prize-as-the-best-smart-cityproject-in-the-world-2014-in-barcelona-and-has-had-no-real/ 
Copenhagen Capacity. (2020b). Copenhagen is the World's Smartest City. Erişim Adresi (09.08.2020): https://www.copcap.com/newslist/2014/copenhagen-is-the-worlds-smartest-city

Copenhagen Capacity. (2020c). Smart City in Greater Copenhagen. Erişim Adresi (09.08.2020): https://www.copcap.com/set-up-a-business/key-sectors/smart-city

Copenhagen Solutions Lab. (2020). Erişim Adresi (09.08.2020): https://cphsolutionslab.dk/en

Cömertler, S. (2020). Yaşanabilir Kentler İçin Yeşil Alanlar, Yeşil Başkent Kopenhag'dan Öğrenmek. Mimarlık, Planlama ve Tasarım Alanında Akademik Çalışmalar (Ed.: B. Manzak), Gece Kitaplığı, Ankara, s. 267-285.

Dameri, R. P. (2013) Searching for Smart City Definition: A Comprehensive Proposal. International Journal of Computers \& Technology, 11(5), 2544-2551.

Danish Ministry of the Environment (2012). Spatial Planning in Denmark. Danish Ministry of the Environment, Denmark.

Deloitte-Vodafone. (2016). Akıllı Şehir Yol Haritası. (https://www.vodafone.com.tr/Vodafone Business/iot/pdf/akilli-sehir-yol-haritasi.pdf)

Djahel, S., Doolan, R., Muntean, G. M. ve Murphy, J. (2015). A Communications-oriented Perspective on Traffic Management Systems for Smart Cities: Challenges and Innovative Approaches. IEEE Communications Surveys \& Tutorials, 17, 125-151.

Emaldi, M., Aguilera, U., López-de-Ipiña, D. ve Pérez-Velasco, J. (2017). Towards Citizen Co-Created Public Service Apps. Sensors, 17(6), 1265.

Erbay, E. R. ve Özden M. (2018). Kentler Sürdürülebilir Kalkınma Hedeflerini Gerçekleştirmeye Nasıl Yardımcı Olabilirler? Social Sciences Research Journal, 7(4), 255-268.

Eremia, M., Toma, L. ve Sanduleac, M. (2017). The Smart City Concept in the 21st Century. Procedia Engineering, 181, 12-19.

European Parliament. (2014). Mapping Smart Cities in the EU. Directorate General for Internal Policies Policy Department, 28-30.

Farhangi, H. (2010). The Path of the Smart Grid. IEEE Power and Energy Magazine, 8(1), 18-28.

Finn, R. L. ve Wadhwa, K. (2014). The Ethics of Smart Advertising and Regulatory Initiatives in the Consumer Intelligence Industry. INFO, 16(3), 22-39.

Giffinger, R. ve Gudrun, H. (2010). Smart Cities Ranking: An Effective Instrument for The Positioning of the Cities. ACE: Architecture, City and Environment, 12, 7-26.

Goyal, S., Mundra, U. ve Shetty, S. (2019). Smart Agriculture Using loT. International Journal of Computer Science and Mobile Computing, 8(5), 143-148.

Gretzel, U., Sigala, M., Xiang, Z. ve Koo, C. (2015). Smart Tourism: Foundations and Developments. Electronic Markets, 25(3), 179-188.

Gürsoy, O. (2019). Akıllı Kent Yaklaşımı ve Türkiye'deki Büyükşehirler İ̧in Uygulama Imkânları. Yayınlanmamaış Yüksek Lisans Tezi, Hacettepe Üniversitesi Sosyal Bilimler Enstitüsü, Ankara.

Harris, J. M. (2000). Basic Principles of Sustainable Development. Global Development and Environment Institute Working Paper:00-04, Tufts University, USA.

Hollands, R. (2008). Will the Real Smart City Please Stand Up? City: Analysis of Urban Trends, Culture, Theory, Policy, Action, 12(3), 303-320.

IMD (2019). Smart City Index. IMD World Competitiveness Center.

Johannessen, M. R. ve Berntzen, L. (2018). The Transparent Smart City. Rodríguez Bolívar, M.P. (ed.) Smart Technologies for Smart Governments (67-94)., Cham: Springer. 
Johnston, P., Everard, M., Santillo, D. ve Robèrt, K. (2007). Reclaiming the Definition of Sustainability. Environmental Science and Pollution Research International, 14(1) 60-66.

Karakurt Tosun, E. (2019). Sürdürülebilir Kentleşme. Bursa: Dora Basım-Yayın.

Kondepudi, S. (2014). Smart Sustainable Cities: An Analysis of Definitions. The ITU-T Focus Group for Smart Sustainable Cities.

Kunzmann, K. R. (2014). Smart Cities: A New Paradigm of Urban Development. Crios, 1, 17.

Kylili, A. ve Fokaides, P. (2015). European Smart Cities: The Role of Zero Energy Buildings. Sustainable Cities Society, 15, 86-95.

Lau, B. P. L., Wijerathne, N., Ng, B. K. K. ve Yuen, C. (2018). Sensor Fusion for Public Space Utilization Monitoring in a Smart City. IEEE Internet of Things Journal, 5(2), 473-481.

Lazaroiu, G. C. ve Roscia, M. (2012). Definition Methodology for the Smart Cities Model. Energy, 47(1), 326-332.

Mora, L. ve Bolici, R. (2017). How to Become a Smart City: Learning from Amsterdam. (Ed. Bisello, A., Vettorato, D., Stephens, R., Elisei, P.). Smart and Sustainable Planning for Cities and Regions, Springer Publishing, Switzerland, 251-266.

Mortensen, J., Rohde, F., Kristiansen, K., Kanstrup-Clausen, M. ve Lubanski, M. (2012). Danish Smart Cities: Sustainable Living in an Urban World an Overview of Danish Smart City Competencies. Copenhagen Cleantech Cluster.

Mulligan, C. E. ve Olsson, M. (2013). Architectural Implications of Smart City Business Models: An Evolutionary Perspective. IEEE Communications Magazine, 51(6), 80-85.

Nijholt, A. (2017). Mischief Humor in Smart and Playable Cities. Nijholt, A. (ed.) Playable Cities (235253). Singapore: Springer.

Nowicka, K. (2014). Smart City Logistics on Cloud Computing Model. Procedia - Social and Behavioral Sciences, 151, 266-281.

Özgen, N. (2019). Sürdürülebilirlik Kavramı ve Kullanım Alanları. Özgen, N. E., Kahyaoğlu, M. (Ed.) Sürdürülebilir Kalkınma, Ankara: Pegem Akademi. 2-37.

Parra, L., Sendra, S., Lloret, J. ve Bosch, I. (2015). Development of a Conductivity Sensor for Monitoring Groundwater Resources to Optimize Water Management in Smart City Environments. Sensors, 15(9), 20990-21015.

Pelletier, M.P., Tre'panier, M. ve Morency, C. (2011). Smart Card Data Use in Public Transit: A Literature Review. Transportation Research Part C: Emerging Technologies, 19(4), 557-568.

Peng, H., Bohong, Z. ve Qinpei, K. (2017). Smart City Environmental Pollution Prevention and Control Design Based on Internet of Things. IOP Conference Series: Earth and Environmental Science, 94(1), 012174.

Sanchez-Corcuera, R., Nunez-Marcos, A., Sesma-Solance, J., Bilboa-Jayo, A., Mulero, R., Zulaika, U., Azkune, G. ve Almeida, A. (2019). Smart Cities Survey: Technologies, Application Domains and Challenges for the Cities of the Future. International Journal of Distributed Sensor Networks, 15(6), 1-36.

Serrenho, T. ve Bertoldi, P. (2019). Smart Home and Appliances: State of the Art - Energy, Communications, Protocols, Standards. European Union, Luxembourg.

Sınmaz, S. (2013). Yeni Gelişen Planlama Yaklaşımları Çerçevesinde Akıllı Yerleşme Kavramı ve Temel İlkeleri. Megaron, 8(2), 76-86.

Silva, B. N., Khan, M. ve Han, K. (2018). Towards Sustainable Smart Cities: A Review of Trends, Architectures, Components, and Open Challenges in Smart Cities. Sustainable Cities Society, 38, 697-713. 
Solanas, A., Patsakis, C., Conti, M., Vlachos, I.S., Ramos, V., Falcone, F., Postolache, O., PérezMartínez, P.A., Di Pietro, R., Perrea, D. N. ve Martínez-Ballesté, A. (2014). Smart Health: A Context-aware Health Paradigm within Smart Cities. IEEE Communications Magazine, 52(8), 74-81.

Ssekatawa, S. (2016). Towards More Socially Inclusive Smart Sustainable Cities, A Study of Smart City Districts in the Greater Copenhagen Region. MSc Thesis, The International Institute for Industrial Environmental Economics, Lund, Sweden.

The City of Copenhagen. (2020a). Copenhagen Facts. Erişim Adresi (09.08.2020): https://international.kk.dk/artikel/copenhagen-facts

The City of Copenhagen. (2020b). Smart City. Erişim Adresi (09.08.2020): https://urbandevelopmentcph.kk.dk/indhold/smart-city

Topal, A. S. ve Arpacıoğlu, Ü. (2020). Mimarlıkta Akıllı Malzeme. Mimarlık Bilimleri ve Uygulamaları Dergisi, 5(2), 241-254.

Ulusoy, M. (2017). Akıllı Şehirler. Yayınlanmamış Yüksek Lisans Tezi. İstanbul Bilgi Üniversitesi Sosyal Bilimler Enstitüsü, İstanbul.

United Nations. (2019a). World Population Prospects 2019: Highlights. United Nations, Department of Economic and Social Affairs, Population Division (ST/ESA/SER.A/423).

United Nations. (2019b). World Urbanization Prospects: The 2018 Revision. United Nations, Department of Economic and Social Affairs, Population Division (ST/ESA/SER.A/420). New York: United Nations.

United Nations (2017). New Urban Agenda. United Nations Conference on Housing and Sustainable Urban Development (Habitat III). www.habitat3.org

United Nations. (2015). Transforming Our World: The 2030 Agenda for Sustainable Development. Resolution Adopted by the General Assembly on 25 September 2015 (A/RES/70/1).

United Nations.(1987). Report of the World Commission on Environment and Development: Our Common Future. United Nations.

Uskov, V., Howlett, R. J., Jain, L. C. (Ed.) (2015). Smart Education and Smart e-Learning, Springer.

Voytenko, Y., McCormick, K., Evans, J. ve Schliwa, G. (2016). Urban Living Labs for Sustainability and Low Carbon Cities in Europe: Towards a Research Agenda. Journal for Cleaner Pro., 45-54.

Yaylı, H. ve Gönültaş, Y. C. (2018). Habitat Konferanslarına Tarihsel Bir Bakış. H. Yaylı (Ed.) KAYSEM 12 e-bildiriler Kitabı, Kırıkkale Üniversitesi. 870-893.

Yin, C. T., Xiong, Z., Chen, H., Wang, J. Y., Cooper, D. ve David, B. (2015). A Literature Survey on Smart Cities. Science, China Information Sciences, 58(10), 1-18. 